\title{
ÉREMMEL KELTEZETT KORA ÁRPÁD-KORI LELETEGYÜTTES ESZTERGOMBÓL
}

\author{
LOVAG ZsUZSA*
}

\begin{abstract}
The study presents the pottery finds from a pit uncovered under the eastern wing of the monastery
\end{abstract} excavated at Esztergom-Primás-sziget, dated by a coin of András I (1046-1060).

Keywords: early Árpádian Age, Esztergom, pottery

A közlemény az esztergomi Prímás-szigeti kolostor keleti szárnya alatt feltárt, I. András (1046-1060)-éremmel keltezett gödör kerámialeleteit mutatja be.

Kulcsszavak: kora Árpád-kor, Esztergom, kerámia

Az esztergomi Prímás-szigeti kolostor 1979-1992 között folytatott feltárásáról készült összefoglalás 2014-ben jelent meg. ${ }^{1}$ Az ásatás során napvilágra került óriási mennyiségú cserépanyagból a kötetben csupán a jellegzetes darabokról jelentek meg fotók, a korhatározó leletek leírása a szövegben olvasható. A keleti kolostorszárny alatt feltárt hulladékgödörben egy I. András (1046-1060)-érem is előkerült. Tekintettel arra, hogy az Árpád-kori kerámia időrendjének pontosítása jelenleg erősen foglalkoztatja a kutatást, felmerült az igény a hulladékgödör leleteinek részletes közlésére.

A hulladékgödröt a keleti kolostorszárny délról számított harmadik helyisége alatt bontottuk $\mathrm{ki}$, az igen erósen bolygatott 83. szelvényben. ${ }^{2}$ A rétegviszonyok és a leletanyag tanúsága szerint a keleti szárnyat csak a 13. század végén vagy a

* A kézirat érkezett: 2016. február 29.

* Lovag Zsuzsa. 1145 Budapest, Újvilág u. 42-44.; zsuzsalovag@ gmail.com

1 Lovag 2014. A leletek az esztergomi Balassa Bálint Múzeum gyújteményébe kerültek.

2 LOVAG 2014. 31, 23. ábra. A metszetrajzon hibás a számozás, a hulladékgödröt a 8 . szám jelöli. A hivatkozott kötetben a 31. tábla 6. és a 32. tábla 2., 3., 5., 6., 9. számmal jelölt cseréptöredék helyesen a jelen közleményben tárgyalt gödör lelete.
14. század elején emelték, járószintje alatt vastag, Árpád-kori cserepekkel keltezett hulladékréteget, valamint több, kőből és folyami kavicsból készült kemencét találtunk. Ezek egyikét az éremmel keltezett hulladékgödör fölé építették.

A gödörben állatcsontokon kívül kizárólag kisebb-nagyobb fazekak darabjait találtuk. A leletegyüttesből hiányoztak a finomabb kerámiatöredékek, a fedők vagy a kolostor területén máshol igen súrún előforduló cserépbográcsok töredékei.

A kihajló peremek többsége lekerekített vagy ferdén levágott, kisebb részben - $k b$. az anyag ötödénél - előfordulnak szalagperemek is. A peremek rövid nyakhoz csatlakoznak. A díszítések között meglehetősen ritka volt és minden esetben közvetlenül a fazék nyaka alatt jelent meg az ún. "körömbenyomás-sor”. Lejjebb az edény testét bekarcolt hullámvonal- vagy vízszintes vonalköteg díszíti.

Elsősorban szalagperemes fazekakon fordul elő a sưrü, ferde bemetszésekből álló sor, ugyancsak közvetlenül az edény nyaka alatt. Néhány, kizárólag nagyobb edényekhez tartozó oldaltöredéken négyzetes végú szerszámmal benyomkodott, körbefutó pontsorokból álló díszítés jelenik meg. Viszonylag kevés a nagyobb közökkel be- 
karcolt csiga- vagy hullámvonalas díszítésú töredék.

A leggyakoribb a fogazott szerszámmal bekarcolt vonalköteg és hullámvonalköteg, néhány darabon együtt is előfordulnak. Két vonalköteges díszítésú edény nyakán ferdén benyomott pontsor volt, amit ugyanazzal a szerszámmal készítettek, mint a vonalkötegeket.

A lekerekített peremú edényeken a bekarcolás többnyire magasan, közvetlenül a rövid nyak alatt kezdődik és - néhány töredékból ítélve 2-3 cm-rel a fenék fölött ér véget. Három olyan peremtöredék is előkerült, ahol magán a kihajló perem felületén volt hullámvonal-köteges bekarcolás.

A fenékbélyegek egyszerú keresztek vagy a száraikat áthúzó vonalakkal bővítettek, egy pedig szvasztika formájú.

\section{KATALÓGUS}

Fazék perem-és faltöredéke (1. kép 2). M.: 9, illetve $10 \mathrm{~cm}$; pátm.: $11 \mathrm{~cm}$; falvast.: $1 \mathrm{~cm}$

Durva szemú kaviccsal kevert agyag. Kézikorongolt, vegyes égetésú, foltosan égett sötétszürke, törésfelülete egyenletes sötétszürke. Belseje világosszürke, pereme fekete. Közepesen kihajló, lekerekedó perem, a rövid nyak alatt közvetlenül ferde fésúbeszurkálás. Oldalán két sorban egyenes vonalköteg, ugyanazzal a hatfogú szerszámmal bekarcolva, mint a ferde beszurkálás. Ltsz.: 2008.1.925. (két darab)

Fazék perem- és faltöredéke (1. kép 3). M.: 5,9 cm; pátm.: $15 \mathrm{~cm}$; falvast.: $0,6 \mathrm{~cm}$

Apró kaviccsal kevert homokos agyag. Kézikorongolt, vegyes égetésú, világosbarna, szürke foltos, törésfelülete kívül szürke, belül világosbarna. Közepesen kihajló, lekerekedő perem, a rövid nyak alatt két sorban egyenes, ötfogú szerszámmal bekarcolt vonalköteg. Ltsz.: 2008.1.928.

Fazék perem- és faltöredéke (3. kép 8). M.: 6,8 cm; pátm.: $19 \mathrm{~cm}$; falvast.: $0,7-0,8 \mathrm{~cm}$

Homokkal kevert agyag. Kézikorongolt, vegyes égetésú, világos szürkésbarna, szürke foltos. Törésfelülete egyenletes, világos szürkésbarna. Közepesen kihajló, lekerekedő perem, a rövid nyak alatt közvetlenül, sürú sorokban hétfogú szerszámmal bekarcolt hullámvonalkötegek. Kihajló peremén belül sứrú amplitúdójú, ötfogú szerszámmal bekarcolt hullámvonalköteg. Ltsz.: 2008.1.951.

Fazék perem- és faltöredéke (1. kép 6). M.: 6,4cm; pátm.: $14 \mathrm{~cm}$; falvast.: $0,5 \mathrm{~cm}$

Homokkal kevert agyag. Kézikorongolt, vegyes égetésú, világosbarna, szürke foltos, törésfelülete világosszürke. A közepesen kihajló, lekerekedő peremen körbefutó kettős vonal, belül súrú amplitúdójú, kétfogú szerszámmal bekarcolt szabálytalan hullámvonalköteg. Rövid nyaka alatt sứrú, helyenként egymást metszó vonalkötegek. Ltsz.: 2008.1.929.
Fazék perem-és faltöredéke (2. kép 5). M.: 8 cm; pátm.: 19 $\mathrm{cm}$; falvast.: $0,7 \mathrm{~cm}$

Homokkal kevert agyag. Kézikorongolt, vegyes égetésú, világosbarna, szürke foltos, külsó oldalán vöröses engobe, törésfelülete kívül vörös, középen világos barnásszürke, belül sötétszürke. Erősen kihajló, lekerekedő perem, rövid nyak. Vállán és oldalán négyfogú szerszámmal bekarcolt egymást metsző hullámvonalkötegek. Ltsz.: 2008.1.937.

Fazék perem- és faltöredéke (2. kép 2). M.: $7 \mathrm{~cm}$; pátm.: $15 \mathrm{~cm}$; falvast.: 0,7 cm (nyaknál 0,9 cm)

Homokkal kevert agyag. Kézikorongolt, vegyes égetésú, világosbarna, szürke foltos, törésfelülete kívül-belül világosbarna, középen szürke. Erősen kihajló, lekerekedő perem, rövid nyak. Vállán és oldalán széles, helyenként egymást metsző vonalakból álló egyenes vonalkötegek. Ltsz.: 2008.1.941.

Fazék perem- és faltöredéke (3. kép 11). M.: 8 cm; pátm.: $19 \mathrm{~cm}$; falvast.: $0,6 \mathrm{~cm}$

Apró kavicsos homokkal kevert agyag. Kézikorongolt, vegyes égetésú, világosbarna, világosszürke foltos, törésfelülete világosbarna. A közepesen kihajló, lekerekedő peremen körbefutó hornyolatok. Rövid nyaka alatt súrún beböködött nagyobb pontsor, alatta súrú, ötfogú szerszámmal ferdén beböködött sor. Alatta két sorban egyenetlen fogú szerszámmal bekarcolt egyenes vonalkötegek. Ltsz.: 2008.1.952. (három darabból ragasztva)

Fazék perem-és faltöredéke (3. kép 10). M.: 3,7 cm; pátm.: $14 \mathrm{~cm}$; falvast.: $0,7 \mathrm{~cm}$

Apró kavicsos homokkal kevert agyag. Kézikorongolt, vegyes égetésú, világosszürke, sötétszürke foltos, törésfelülete világos és sötétszürke. Közepesen kihajló, lekerekedó, enyhén bordázott perem, rövid nyak. Vállán sứrú, ötfogú szerszámmal bekarcolt hullámvonalköteg. Ltsz: 2008.1.954.

Fazék perem-és faltöredéke (2. kép 4). M.: 5,7 cm; pátm.: $20 \mathrm{~cm}$; falvast.: $0,7 \mathrm{~cm}$

Apró kavicsos homokos agyag. Kézikorongolt, vegyes égetésú, vörösesbarna, szürke foltos, törésfelülete kívülbelül vörösesbarna, középen sötétszürke. Enyhén kihajló lekerekedő perem, rövid nyak. Oldalán egyenetlenül fogazott szerszámmal sekélyen bekarcolt egyenes vonalkötegek. Ltsz.: 2008.1.936.

Fazék perem- és faltöredéke (1. kép 4). M.: 7 cm; pátm.: $20 \mathrm{~cm}$; falvast.: $0,7 \mathrm{~cm}$

Apró kavicsos homokkal kevert agyag. Kézikorongolt, vegyes égetésú, világosbarna, világosszürke foltos, törésfelülete kívül-belül világosbarna, középen sötétszürke. Enyhén kihajló, lekerekedő perem, rövid nyak. Vállán és oldalán laza amplitúdójú, szabálytalanul bekarcolt hullámvonalak. Ltsz.: 2008.1.927.

Fazék perem- és faltöredéke (3. kép 9). M.: $5 \mathrm{~cm}$; pátm.: $14 \mathrm{~cm}$; falvast.: $0,5-0,7 \mathrm{~cm}$

Apró kavicsos, csillámos homokkal kevert agyag. Kézikorongolt, vegyes égetésú, világosszürke, sötétszürke foltos, törésfelülete világos- és sötétszürke. Enyhén kihajló, lekerekített perem, rövid nyak. Az edény vállán 


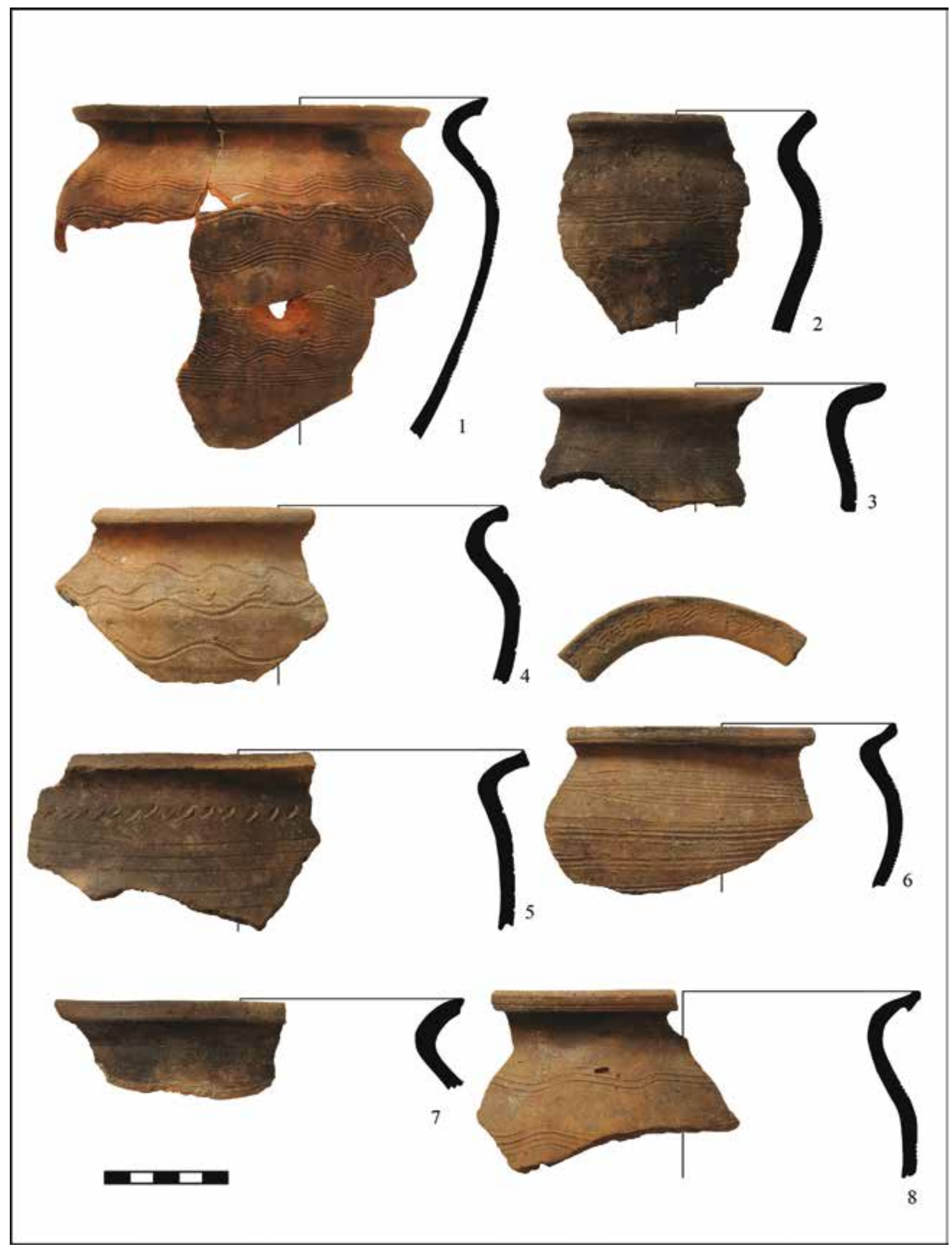

1. kép. Esztergom, Prímás-szigeti apácakolostor. A keleti szárny alatt feltárt, éremmel keltezett gödör leletei. 1: 2008.1.924+943; 2: 2008.1.925; 3: 2008.1.928; 4: 2008.1.927; 5: 2008.1.930; 6: 2008.1.929; 7: 2008.1.935; 8: 2008.1.931.

Abb. 1. Esztergom, Prímás-sziget. Münzdatierte Funde aus einer Müllgrube unter dem östlichen Gebäudeflügel des Nonnenklosters. 1: 2008.1.924+943; 2: 2008.1.925; 3: 2008.1.928; 4: 2008.1.927; 5: 2008.1.930; 6: 2008.1.929; 7: 2008.1.935; 8: 2008.1.931. 


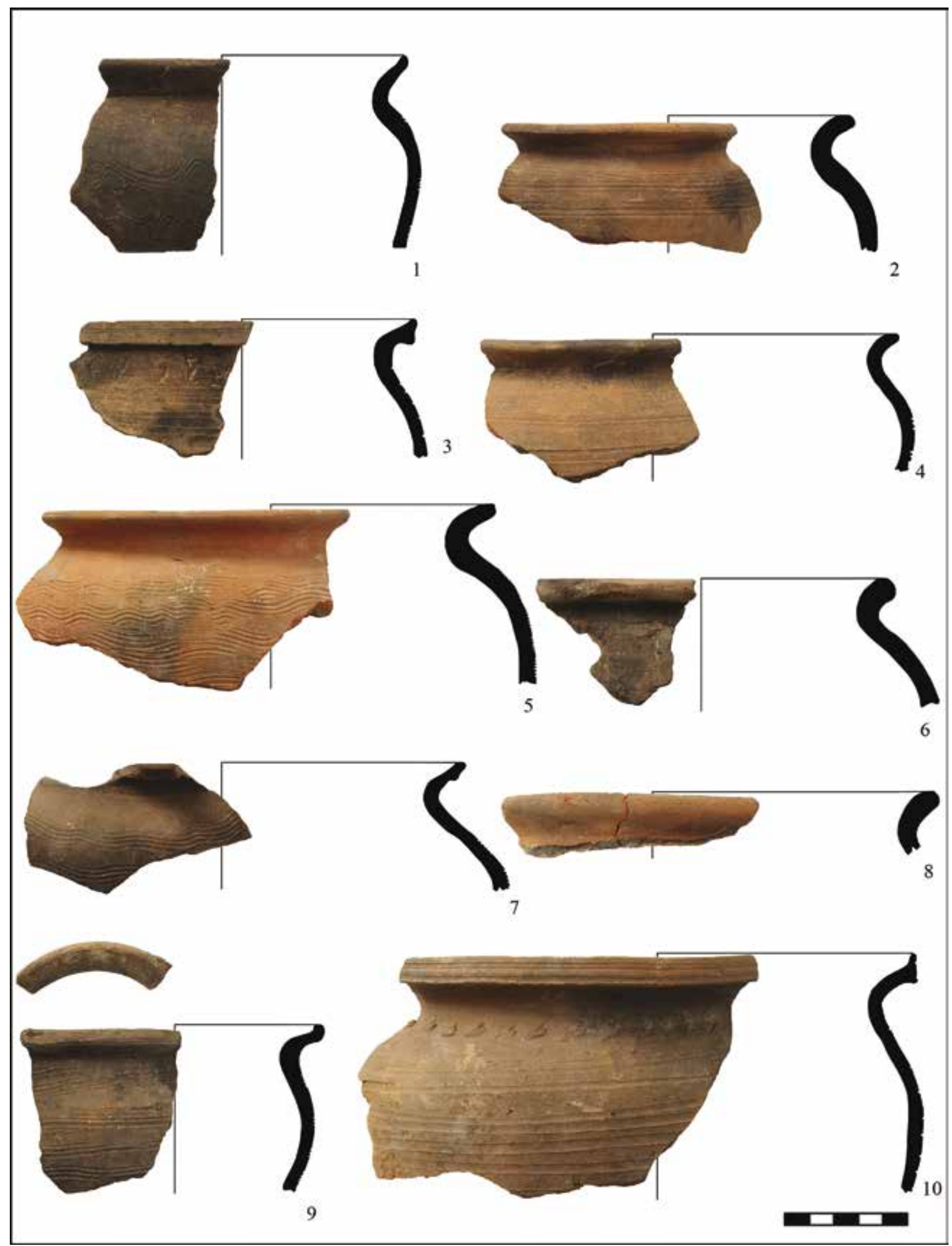

2. kép. Esztergom, Prímás-szigeti apácakolostor. A keleti szárny alatt feltárt, éremmel keltezett gödör leletei. 1: 2008.1.932; 2: 2008.1.941; 3: 2008.1.934; 4: 2008.1.936; 5: 2008.1.937; 6: 2008.1.938; 7: 2008.1.939; 8: 2008.1.944; 9: 2008.1.933; 10: 2008.1 .940$.

Abb. 2. Esztergom, Prímás-sziget. Münzdatierte Funde aus einer Müllgrube unter dem östlichen Gebäudeflügel des Nonnenklosters. 1: 2008.1.932; 2: 2008.1.941; 3: 2008.1.934; 4: 2008.1.936; 5: 2008.1.937; 6: 2008.1.938; 7: 2008.1.939; 8: 2008.1.944; 9: 2008.1.933; 10: 2008.1.940. 
sekélyen bekarcolt széles, egyenes vonalköteg. Ltsz.: 2008.1.953. (két darabból ragasztva)

Fazék perem-és faltöredéke (2. kép 1). M.: 7,6 cm; pátm.: $15 \mathrm{~cm}$; falvast.: $0,6 \mathrm{~cm}$

Homokkal kevert agyag. Kézikorongolt, vegyes égetésú, világosbarna, szürke foltos, törésfelülete egyenletes világosbarna, szürke. A szögben törő, elvékonyodó, lekerekített perem tövénél árok. Rövid nyaka alatt közvetlenül négyágú szerszámmal sekélyen bekarcolt hullámvonalköteg, alatta két sorban hasonló. Ltsz.: 2008.1.932.

Fazék perem-és faltöredéke (4. kép 2). M.: 4,8 cm; pátm.: $20 \mathrm{~cm}$; falvast.: $0,6 \mathrm{~cm}$

Apró kavicsos homokkal kevert agyag. Kézikorongolt, vegyes égetésü, világosszürke, törésfelülete egyenletes világosszürke. Enyhén kihajló, lekerekített perem, a rövid nyak alatt kezdődő sûrú, egyenes bekarcolt mező Nyakán belül mély, ferde bevágások. Ltsz.: 2008.1.957.

Fazék perem-és faltöredéke (3. kép 13). M.: 2,8 cm; pátm.: $20 \mathrm{~cm}$; falvast.: $0,6 \mathrm{~cm}$

Homokkal kevert agyag. Kézikorongolt, vegyes égetésú, világosbarna, törésfelülete egyenletes világosbarna. Enyhén kihajló, lekerekített perem, a rövid nyakon, közvetlenül a perem alatt ferdén bekarcolt vonalsor, a vonalak perem melletti végén széles gyưrődés. Ltsz: 2008.1.960.

Bögre perem-és faltöredéke (3. kép 3). M.: 3,9 cm; pátm.: $3,8 \mathrm{~cm}$; falvast.: $0,5 \mathrm{~cm}$

Apró kavicsos homokkal kevert agyag. Kézikorongolt, vegyes égetésû, barna-szürke foltos, törésfelülete barnaszürke. Kis fazék erősen kihajló, elvékonyodó, lekerekített pereme tövénél hornyolat, rövid nyak. Vállán háromágú szerszámmal bekarcolt hullámvonalköteg. Ltsz.: 2008.1.946

Bögre perem- és faltöredéke (2. kép 9). M.: 7,1 cm; pátm.: $12 \mathrm{~cm}$; falvast.: $0,6 \mathrm{~cm}$

Homokkal kevert agyag. Kézikorongolt, vegyes égetésú, világosszürke-sötétszürke foltos, törésfelülete világosszürke. Bögre közepesen kihajló, lekerekített peremmel. Rövid nyakán és oldalán négyágú szerszámmal bekarcolt egyenes - helyenként kissé hullámzó - vonalkötegek. Peremén belül négyágú szerszámmal bekarcolt hullámvonalköteg. Ltsz.: 2008.1.933.

Fazék perem-és faltöredéke (2. kép 6). M.: 5,8 cm; pátm.: $16 \mathrm{~cm}$; falvast.: $0,7 \mathrm{~cm}$

Homokkal kevert agyag. Kézikorongolt, vegyes égetésú, világosbarna, sötétszürke foltos, törésfelülete belül barna, kívül sötétszürke. Erősen kihajló lekerekített perem, a rövid nyak alatt két sorban vízszintes, rövid bevágások. Ltsz.: 2008.1.938.

Fazék perem-és faltöredéke (1. kép 5). M.: 7,5 cm; pátm.: $23 \mathrm{~cm}$; falvast.: $0,6 \mathrm{~cm}$

Apró kavicsos homokkal kevert agyag. Kézikorongolt, vegyes égetésú, világosbarna, szürke foltos, törésfelülete szürkésbarna. Közepesen kihajló, kifelé ferdén levágott perem, rövid nyak. Nyaka alatt ferdén beböködött, kissé íves vonalsor, vállán és oldalán egyes körbefutó csigavonal. Ltsz: 2008.1.930.
Fazék perem-és faltöredéke (1. kép 1). M.: 15 cm; pátm.: $16 \mathrm{~cm}$; falvast.: $0,5 \mathrm{~cm}$

Nagyobb kavicsokkal és homokkal kevert agyag. Kézikorongolt, vegyes égetésú, vörösesbarna, szürke foltos, törésfelülete kívül belül vörösesbarna, középen keskeny szürke sáv. Közepesen kihajló, befelé ferdén levágott perem, rövid nyak. A perem belül síkozott. A széles vállú, lefelé szúkülő edény oldalán öt sorban hatágú szerszámmal bekarcolt hullámvonalkötegek, alattuk egyenes vonalköteg. A díszítés a fazék alsó harmadáig leér.

Ltsz.: 2008.1.924. és 2008.1.943. (hat darabból ragasztva)

Fazék perem- és faltöredéke (2. kép 10). M.: 9,2 cm; pátm.: $21 \mathrm{~cm}$; falvast.: $0,7 \mathrm{~cm}$

Finom, csillámos homokkal kevert agyag. Kézikorongolt, vegyes égetésú, világosbarna, szürke foltos, törésfelületén kívül-belül világosbarna engobe, középen sötétszürke. A közepesen kihajló perem függőlegesen levágott, profilált. A perem belső oldalán körbefutó keskeny borda. Rövid nyak alatt ferdén beszurkált, ék alakú vonalsor, vállán és oldalán sekély, sûrü, körbefutó széles vonalsor. Ltsz.: 2008.1.940.

Fazék peremtöredéke (2. kép 8). M.: $3 \mathrm{~cm}$; pátm.: $23 \mathrm{~cm}$; falvast.: $0,9 \mathrm{~cm}$

Homokkal és nagyobb kavicsokkal kevert agyag. Kézikorongolt, vegyes égetésú, vörös, törésfelülete kívülbelül vörös, középen sötétszürke. Közepesen kihajló, lekerekített perem. Ltsz.: 2008.1.944. (két darabból ragasztva)

Fazék perem-és faltöredéke (3. kép 6). M.: 5,5 cm; pátm.: $16 \mathrm{~cm}$; falvast.: $0,6 \mathrm{~cm}$

Kavicsos homokkal kevert agyag. Kézikorongolt, vegyes égetésû, világos vörösbarna, szürke foltokkal, törésfelülete vörösbarna és szürke. Közepesen kihajló, befelé ferdén levágott perem. A rövid nyak alatt háromágú szerszámmal bekarcolt hullámvonalkötegek. Ltsz.: 2008.1.950.

Fazék perem- és faltöredéke (1. kép 8). M.: 7,5 cm; pátm.: $19 \mathrm{~cm}$; falvast.: $0,6 \mathrm{~cm}$

Kavicsos homokkal kevert agyag. Kézikorongolt, vegyes égetésú, világosbarna, szürke foltos, törésfelülete szürke. Közepesen kihajló, belül síkozott, kívül befelé ferdén levágott perem. A perem levágott oldalán körbefutó kettős vonal. Vállán négyágú szerszámmal bekarcolt, vastag vonalú hullámvonalkötegek. Ltsz.: 2008.1.931.

Fazék perem-és faltöredéke (2. kép 7). M.: 6,8 cm; pátm.: $20 \mathrm{~cm}$; falvast.: $0,5 \mathrm{~cm}$

Homokkal kevert agyag. Kézikorongolt, vegyes égetésû, barna, sötétszürke foltos, törésfelülete barna. Közepesen kihajló, befelé ferdén levágott perem, felületén körbefutó hármas vonal. A rövid nyak alatt kettős körbefutó borda. Vállán négyágú szerszámmal bekarcolt, laza amplitúdójú, vastag vonalú hullámvonalkötegek. Ltsz.: 2008.1.939. 

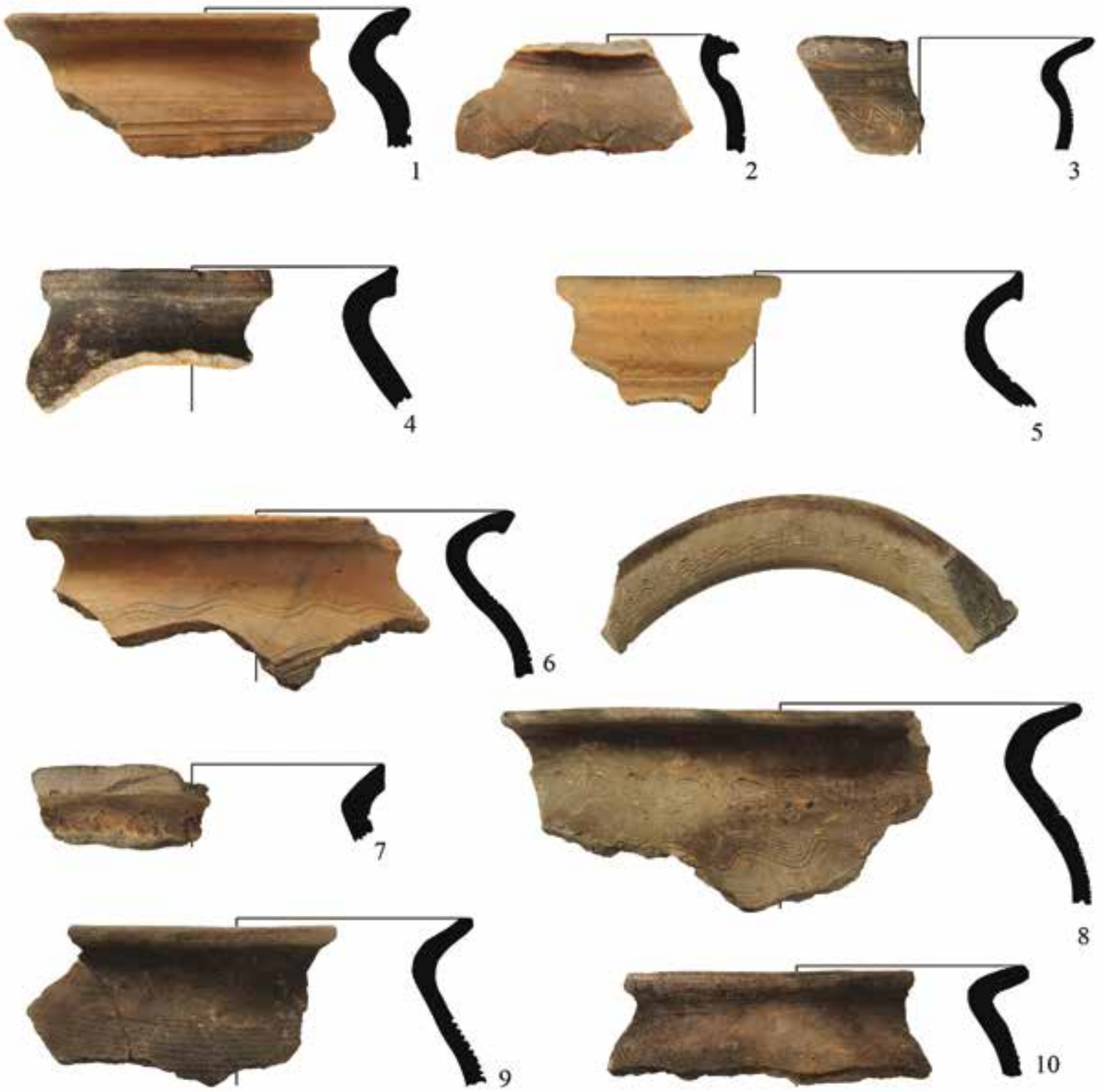

8
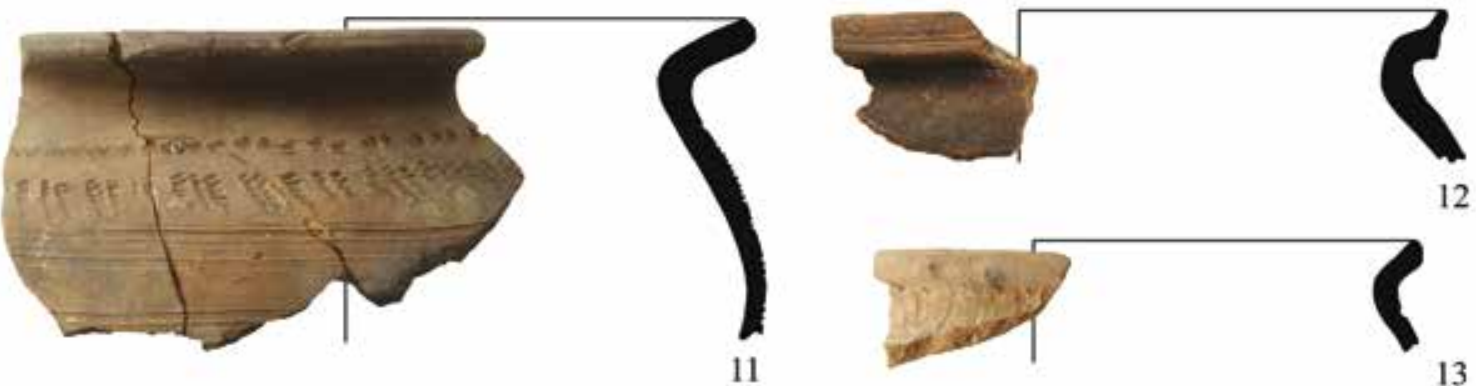

3. kép. Esztergom, Prímás-szigeti apácakolostor. A keleti szárny alatt feltárt, éremmel keltezett gödör leletei. 1: 2008.1.942; 2. 2008.1.945; 3. 2008.1.946; 4: 2008.1.947; 5: 2008.1.948; 6: 2008.1.950; 7: 2008.1.949; 8: 2008.1.951; 9: 2008.1.953; 10: 2008.1.954; 11: 2008.1.952; 12: 2008.1.955; 13: 2008.1.960.

Abb. 3. Esztergom, Prímás-sziget. Münzdatierte Funde aus einer Müllgrube unter dem östlichen Gebäudeflügel des Nonnenklosters. 1: 2008.1.942; 2. 2008.1.945; 3. 2008.1.946; 4: 2008.1.947; 5: 2008.1.948; 6: 2008.1.950; 7: 2008.1.949; 8: 2008.1.951; 9: 2008.1.953; 10: 2008.1.954; 11: 2008.1.952; 12: 2008.1.955; 13: 2008.1.960. 
Fazék perem- és faltöredéke (4. kép 1). M.: 5,8 cm; pátm.: $13 \mathrm{~cm}$; falvast.: $0,4 \mathrm{~cm}$

Homokkal kevert agyag. Kézikorongolt, vegyes égetésú, vörös, szürke foltos, törésfelülete vörös. A közepesen kihajló, egyenesen levágott peremen körbefutó vékony vonalak, a rövid nyakon, közvetlenül a perem alatt súrü, sekély, vékony vonalak. Vállán háromágú szerszámmal bekarcolt, laza amplitúdójú, vastag vonalú hullámvonalkötegek, a két alsó köteg részben egymásba ér. Ltsz.: 2008.1.956.

Fazék perem-és faltöredéke (3. kép 4). M.: 4,5 cm; pátm.: $13 \mathrm{~cm}$; falvast.: $0,6 \mathrm{~cm}$

Apró kavicsos homokkal kevert agyag. Kézikorongolt, vegyes égetésú, világosbarna, sötétszürke foltos, törésfelülete kívül-belül világosbarna, közepén világosszürke. A közepesen kihajló, egyenesen levágott peremen körbefutó vékony, sekély vonalak. Vállán sekély, vastag vonalú hullámvonal. Ltsz.: 2008.1.947.

Fazék perem-és faltöredéke (2. kép 3). M.: 5,6 cm; pátm.: $14 \mathrm{~cm}$; falvast.: $0,4-0,6 \mathrm{~cm}$ (egyenetlen)

Homokkal kevert agyag. Kézikorongolt, vegyes égetésú, barna, sötétszürke foltos, törésfelülete sötétszürke. Az enyhén kihajló, egyenesen levágott peremen körbefutó vékony vonalak, a perem alján széles, ferde bevágások. Rövid nyakán éles vonalú, V alakú bemetszések, alatta sûrû, vastag vonalú, körbefutó sekély vonalak. Ltsz.: 2008.1.934.

Fazék perem-és faltöredéke (3. kép 1). M.: 4,6 cm; pátm.: $13 \mathrm{~cm}$; falvast.: $0,8 \mathrm{~cm}$

Kavicsos homokkal kevert agyag. Kézikorongolt, vegyes égetésú, világosbarna, törésfelületén kívül-belül világosbarna engobe, közepén világosszürke. Közepesen kihajló, befelé ferdén levágott perem, a rövid nyak alatt vastag, sekély körbefutó vonalak. Ltsz.: 2008.1.942.

Fazék perem- és faltöredéke (4. kép 3). M.: $10 \mathrm{~cm}$; pátm.: $18 \mathrm{~cm}$; falvast.: $0,9 \mathrm{~cm}$

Kavicsos homokkal kevert agyag. Kézikorongolt, vegyes égetésú, világosszürke, kívül-belül fehéresszürke engobe, törésfelülete világosszürke. A közepesen kihajló, befelé ferdén levágott peremen kettős hornyolat. Rövid nyakán ferde, íves bemetszések. Vállán és oldalán vastag, háromfogú szerszámmal bekarcolt sekély, szabálytalan közú csigavonal. Ltsz.: 2008.1.959. (két darabból ragasztva)

Fazék perem- és faltöredéke (1. kép 7). M.: 4 cm; pátm.: $18 \mathrm{~cm}$; falvast.: $0,6 \mathrm{~cm}$

Nagyobb kavicsokkal, kagylótöredékekkel, homokkal kevert agyag. Kézikorongolt, vegyes égetésú, világosszürke, fekete foltos, törésfelülete kívül-belül szürke, középen vörösesbarna. Közepesen kihajló, befelé ferdén levágott, lekerekített perem, a rövid nyak alatt súrú, sekélyen bekarcolt vonalköteg. Ltsz.: 2008.1.935.

Bögre perem- és faltöredéke (4. kép 5). M.: 3,7 cm; pátm.: $9 \mathrm{~cm}$; falvast.: $0,8 \mathrm{~cm}$

Homokkal kevert agyag. Kézikorongolt, vegyes égetésú, világosbarna, fekete foltos, törésfelülete egyenletes világosbarna, illetve fekete. A közepesen kihajló, elvéko- nyodó, egyenesen levágott peremen széles hornyolat. Rövid nyak. Ltsz.: 2008.1.958.

Fazék perem-és faltöredéke (3. kép 7). M.: 2,7 cm; pátm.: $12 \mathrm{~cm}$; falvast.: $0,7 \mathrm{~cm}$

Apró kavicsos homokkal kevert agyag. Kézikorongolt, vegyes égetésú, világosbarna, szürke foltos, törésfelülete kívül-belül világosbarna, középen sötétszürke. A közepesen kihajló, egyenesen levágott peremen hornyolat. Rövid nyakán háromszögletú szerszámmal sưrún beböködött sor. Ltsz.: 2008.1.949.

Fazék perem- és faltöredéke (3. kép 5). M.: $5 \mathrm{~cm}$; pátm.: $17 \mathrm{~cm}$; falvast.: $0,6 \mathrm{~cm}$

Apró kavicsos homokkal kevert agyag. Kézikorongolt, vegyes égetésú, világosbarna, világosszürke foltos, törésfelülete kívül világosbarna, belül világosszürke, középen sötétszürke. Közepesen kihajló, egyenesen levágott perem, a nyak alatt kétágú szerszámmal, ferdén beböködött sor, alatta vastag, sekély vonal. Ltsz.: 2008.1.948.

Fazék perem- és faltöredéke (3. kép 12). M.: 3,7 cm; pátm.: $20 \mathrm{~cm}$; falvast.: $0,7 \mathrm{~cm}$

Apró kavicsos homokkal kevert agyag. Kézikorongolt, vegyes égetésú, vörösesbarna, sötétszürke foltos, törésfelülete kívül-belül vörösesbarna, középen sötétszürke. A vízszintesen kihajló, befelé ferdén levágott, fedőhornyos peremen körbefutó kettős vonal. Ltsz.: 2008.1.955.

Oldaltöredék (4. kép 6). M.: 3,2 cm; falvast.: 0,5-0,6 cm

Apró kavicsos homokkal kevert agyag. Kézikorongolt, vegyes égetésú, sötétszürke, törésfelülete egyenletesen sötétszürke. Fazék nyaktöredéke, súrún, ferdén bemetszett vonalsor, alatta vékony és vastag csigavonal. Ltsz.: 2008.1.969.

Oldaltöredék (3. kép 2). M.: 4,5 cm; falvast.: 0,5 cm

Apró kavicsos homokkal kevert agyag. Kézikorongolt, vegyes égetésú, világosbarna, világosszürke foltos, törésfelülete kívül-belül világosbarna, középen sötétszürke. Fazék közepesen kihajló nyaktöredéke, vállán vastag bekarcolt hullámvonal. Ltsz.:2008.1.945.

Oldaltöredék (5. kép 2). M.: 5,7 cm; falvast.: 0,5 cm, nyakrésznél $0,8 \mathrm{~cm}$

Apró kavicsos homokkal kevert agyag. Kézikorongolt, vegyes égetésú, világosbarna, világosszürke foltos, törésfelülete kívül világosbarna engobe, belül világosszürke. Nyak alatt ferde körömbenyomások, alatta lendületes, vastagon bekarcolt, fölül hegyesszögú hullámvonal. Ltsz.: 2008.1.974.

Oldaltöredék (4. kép 11). M.: 6,5 cm; falvast.: 0,7 cm

Homokkal kevert agyag. Kézikorongolt, vegyes égetésú, világosbarna, világosszürke foltos, törésfelülete belül világosbarna, kívül világosszürke. Vállán három sorban négyágú szerszámmal sekélyen bekarcolt hullámvonalköteg, alatta kettôs, vastag csigavonal. Ltsz.: 2008.1.966.

Oldaltöredék (4. kép 15). M.: 8,2 cm; falvast.: 0,5-1 cm.

Homokkal kevert agyag. Kézikorongolt, vegyes égetésû, világosbarna, szürke foltos, törésfelülete kívül-belül világosbarna, középen szürke. Nagyobb fazék, oldalán háromágú szerszámmal sekélyen bekarcolt vonalkötegek, köztük egyes csigavonal. Ltsz.: 2008.1.971. 

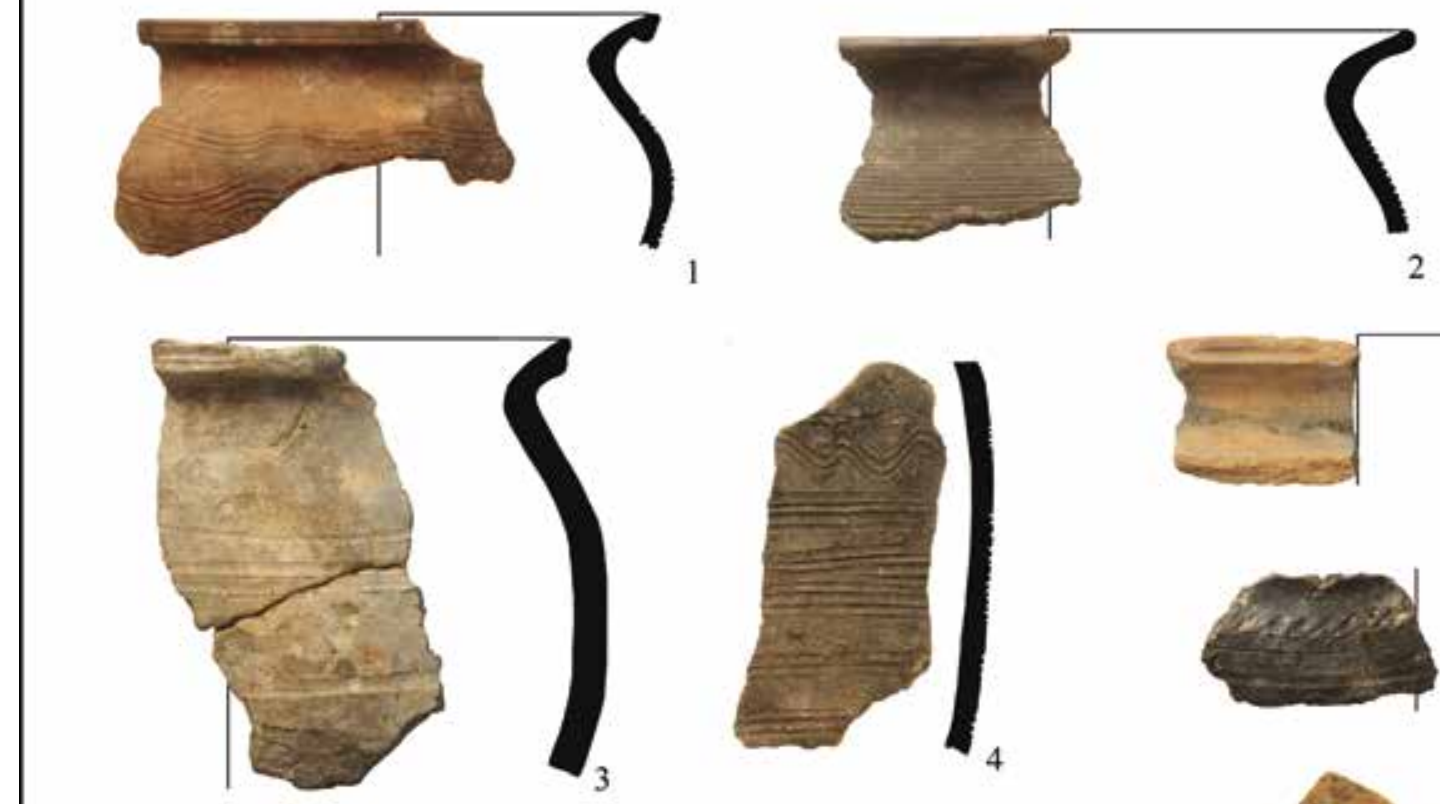

1

2
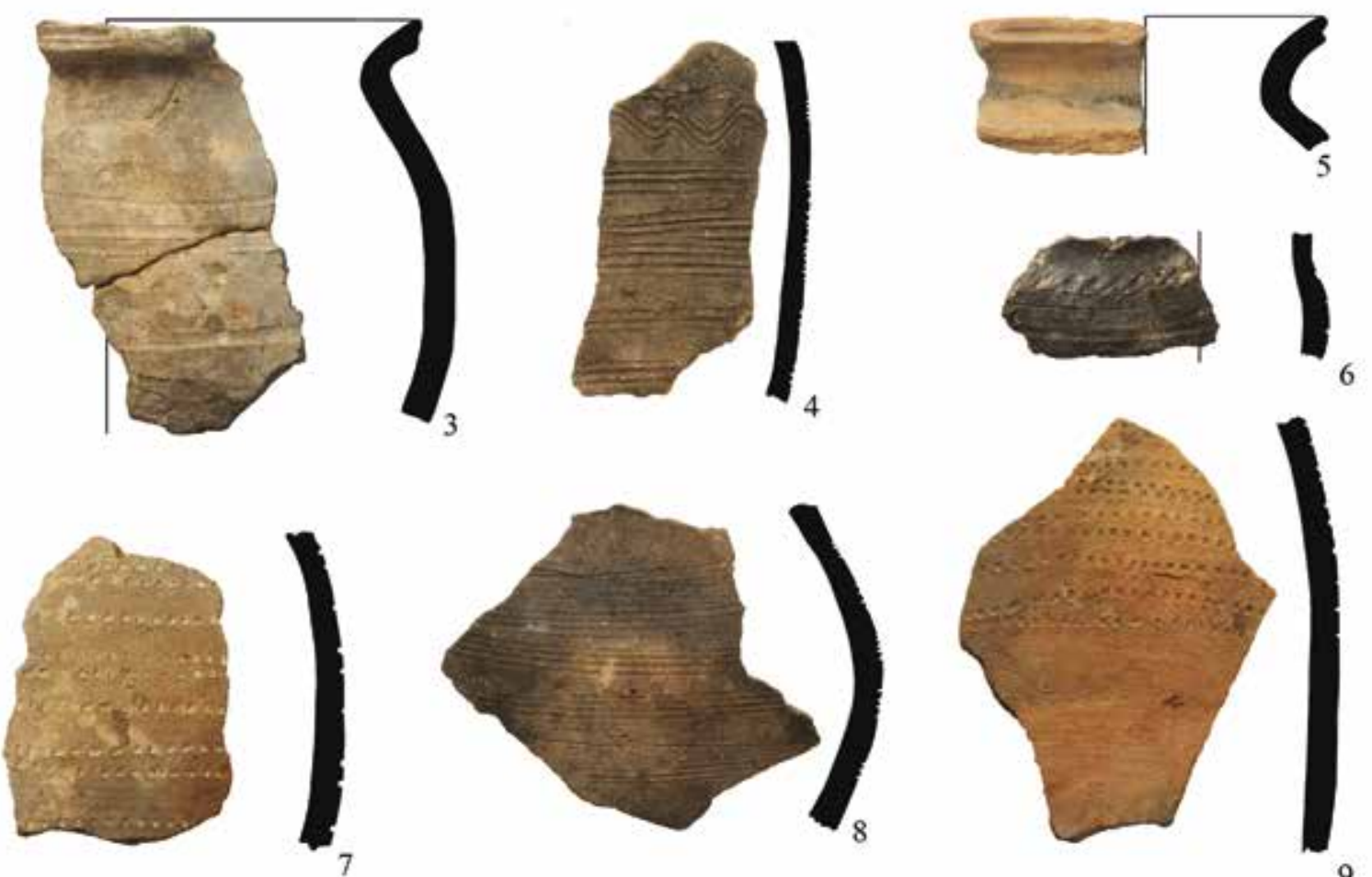

4
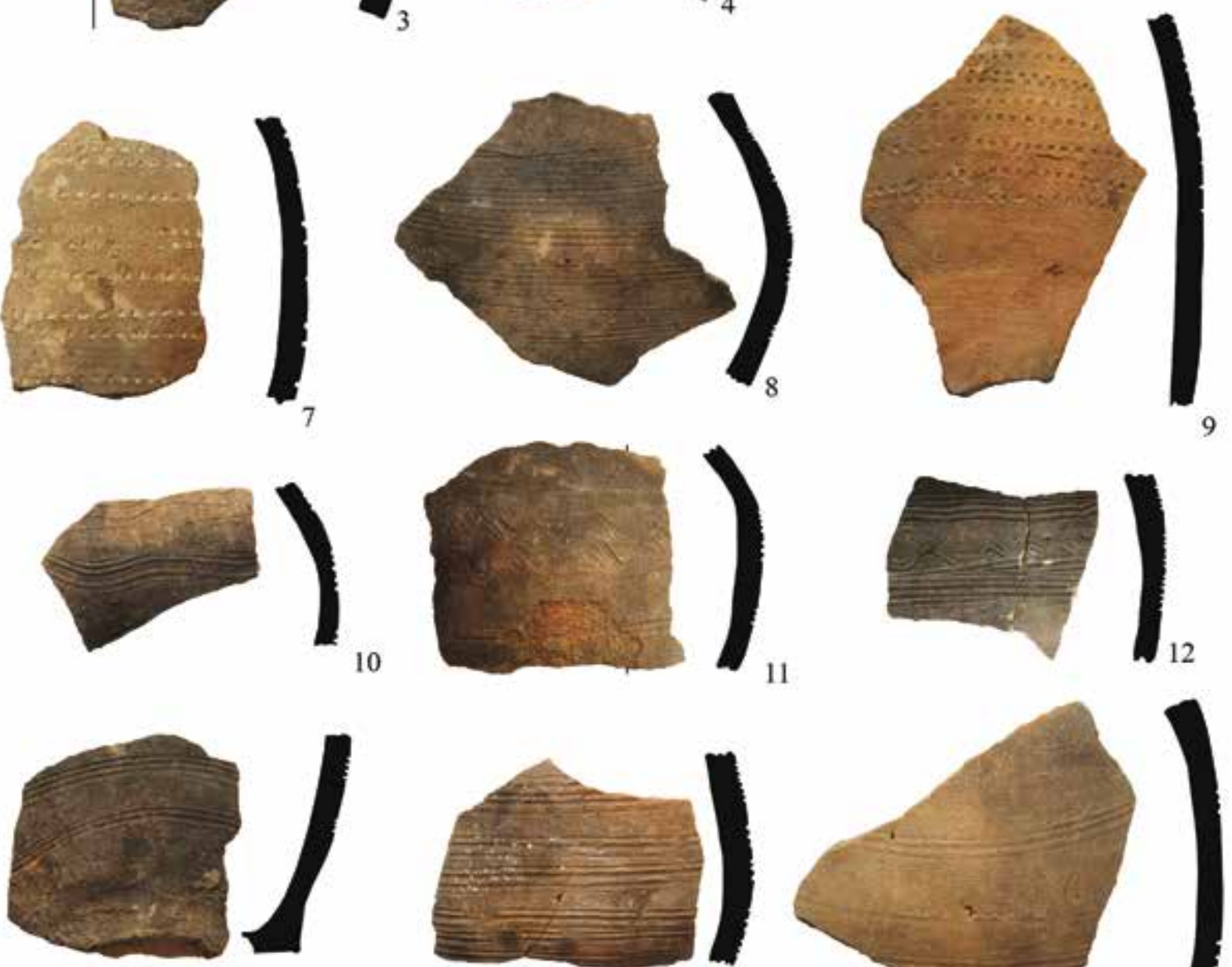

13

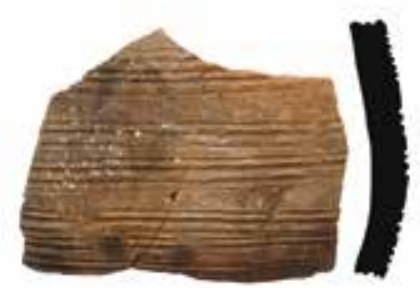

14
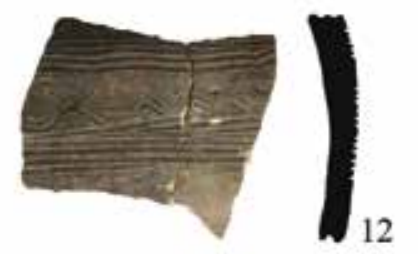

"11
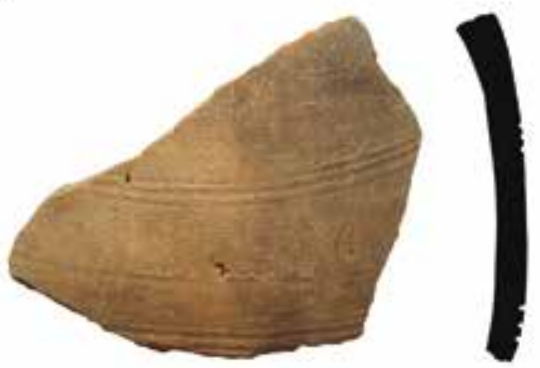

15

4. kép. Esztergom, Prímás-szigeti apácakolostor. A keleti szárny alatt feltárt, éremmel keltezett gödör leletei. 1: 2008.1.956; 2: 2008.1.957; 3: 2008.1.959; 4: 2008.1.961; 5: 2008.1.958; 6: 2008.1.969; 7: 2008.1.963; 8: 2008.1.964; 9: 2008.1.962; 10: 2008.1.965; 11: 2008.1.966; 12: 2008.1.967; 13: 2008.1.972; 14: 2008.1.970; 15: 2008.1.971.

Abb. 4. Esztergom, Prímás-sziget. Münzdatierte Funde aus einer Müllgrube unter dem östlichen Gebäudeflügel des Nonnenklosters. 1: 2008.1.956; 2: 2008.1.957; 3: 2008.1.959; 4: 2008.1.961; 5: 2008.1.958; 6: 2008.1.969; 7: 2008.1.963; 8: 2008.1.964; 9: 2008.1.962; 10: 2008.1.965; 11: 2008.1.966; 12: 2008.1.967; 13: 2008.1.972; 14: 2008.1.970; 15: 2008.1.971. 

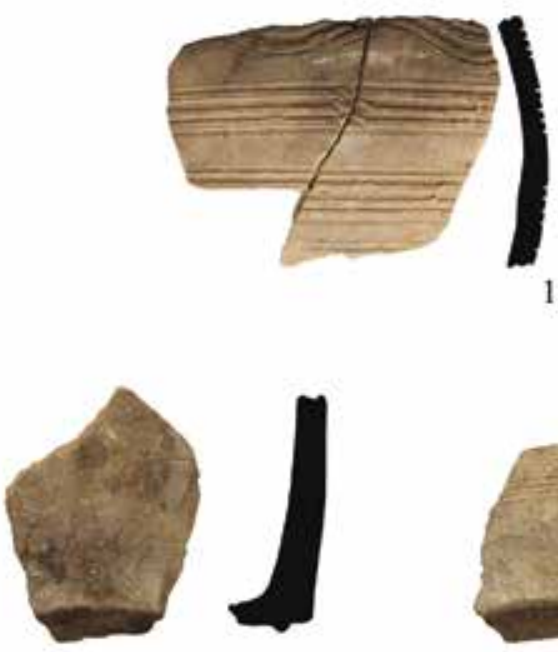

3

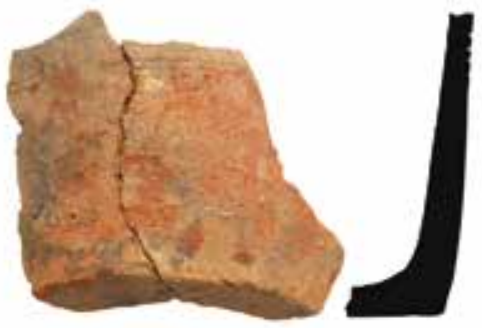

6

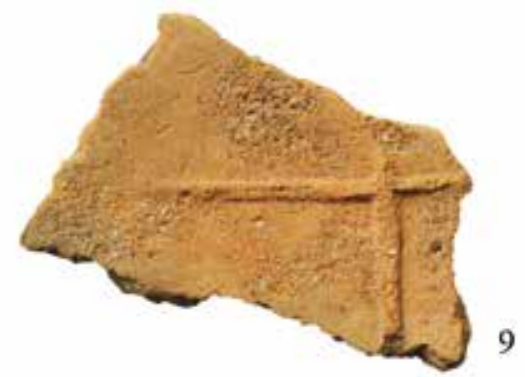

9
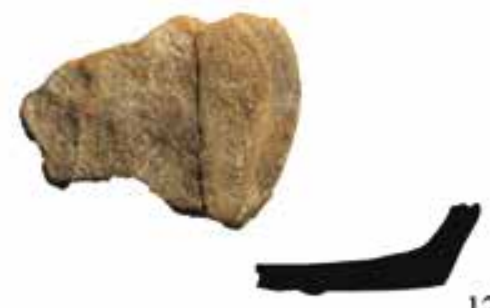

12

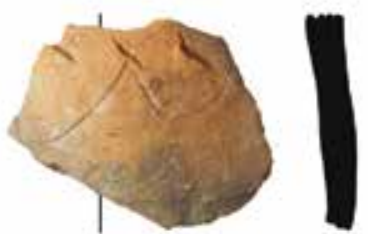

2
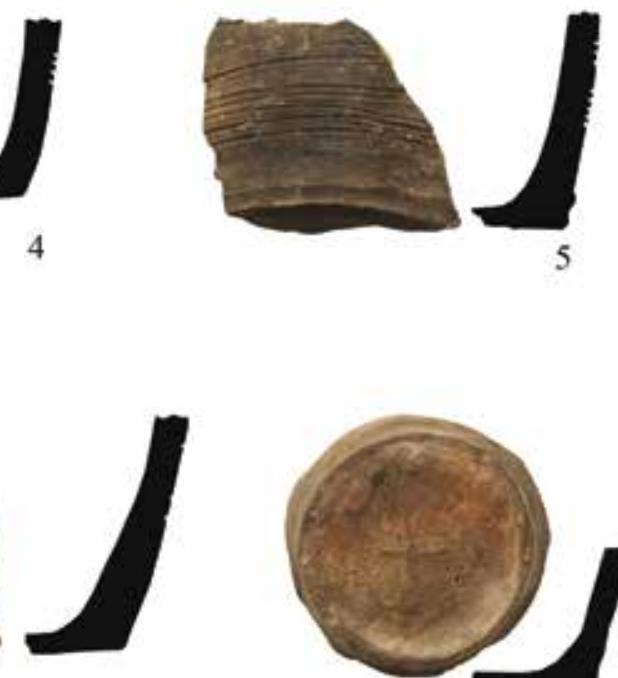

7
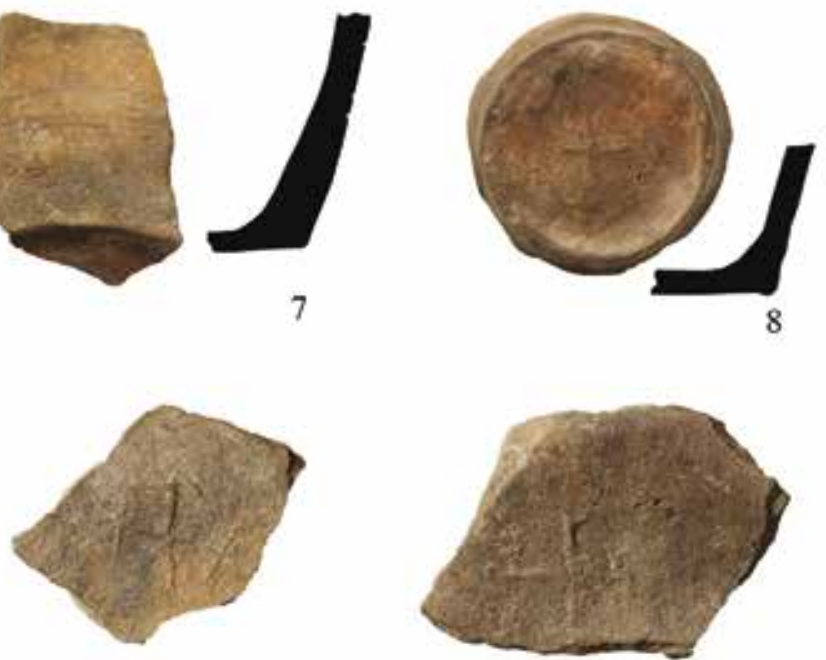

10

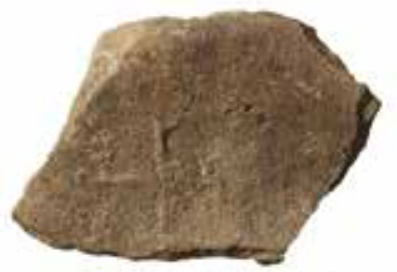

11

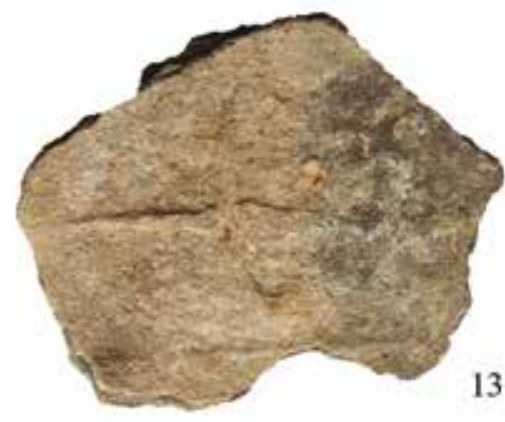

13

5. kép. Esztergom, Prímás-szigeti apácakolostor. A keleti szárny alatt feltárt, éremmel keltezett gödör leletei. 1: 2008.1.973; 2: 2008.1.974; 3: 2008.1.976; 4: 2008.1.977; 5: 2008.1.980; 6: 2008.1.981; 7: 2008.1.982; 8: 2008.1.984; 9: 2008.1.985; 10: 2008.1.986; 11: 2008.1.978; 12: 2008.1.983; 13: 2008.1.979.

Abb. 5. Esztergom, Prímás-sziget. Münzdatierte Funde aus einer Müllgrube unter dem östlichen Gebäudeflügel des Nonnenklosters. 1: 2008.1.973; 2: 2008.1.974; 3: 2008.1.976; 4: 2008.1.977; 5: 2008.1.980; 6: 2008.1.981; 7: 2008.1.982; 8: 2008.1.984; 9: 2008.1.985; 10: 2008.1.986; 11: 2008.1.978; 12: 2008.1.983; 13: 2008.1.979. 
Oldaltöredék (4. kép 8). M.: 8 cm; falvast.: 0,6-0,8 cm

Apró kavicsos homokkal kevert agyag. Kézikorongolt, vegyes égetésú, szürkésbarna, sötétszürke foltos. Fazék váll- és oldaltöredéke, négyágú szerszámmal egymástól egyenetlen távolságra sekélyen bekarcolt vonalkötegek. Ltsz.: 2008.1.964.

Oldaltöredék (4. kép 14). M.: 6,2 cm; falvast.: 0,7-0,9 cm

Apró kavicsos homokkal kevert agyag. Kézikorongolt, vegyes égetésú, szürkésbarna, szürke foltos, belül vörös engobe, törésfelülete belül vörös, kívül szürkésbarna, középen szürke. Oldalán hatágú szerszámmal bekarcolt vonalkötegek. Ltsz.: 2008.1.970. (két darabból ragasztva)

Oldaltöredék (5. kép 1). M.: $6 \mathrm{~cm}$; falvast.: 0,6 cm

Nagyobb kavicsos homokkal kevert agyag. Kézikorongolt, vegyes égetésú, szürkésbarna, sötétszürke foltos, törésfelülete kívül szürkésbarna, belül sötétszürke. Vállán négyágú szerszámmal bekarcolt hullámvonalköteg, alatta több sorban ugyanazzal a szerszámmal készült egyenes vonalkötegek. Ltsz.: 2008.1.973. (két darabból ragasztva)

Oldaltöredék (4. kép 12). M.: 6,3 cm; falvast.: 0,8 cm

Homokkal kevert agyag. Kézikorongolt, vegyes égetésú, sötétszürke, törésfelülete egyenletes sötétszürke. Oldalán egyes hullámvonal, alatta négyágú szerszámmal bekarcolt egyenes vonalkötegek, az egyik elmetsz egy kétágú szerszámmal bekarcolt hullámvonalat. Az alsó egyenes vonalköteg enyhén hullámos. Ltsz.: 2008.1.967. (két darabból ragasztva)

Oldaltöredék (4. kép 4). M.: 9,7 cm; falvast.: 0,5 cm

Nagyobb kavicsos homokkal kevert agyag. Kézikorongolt, vegyes égetésú, belül világosbarna, kívül sötétszürke, törésfelülete belül világosbarna, kívül sötétszürke, középen vörös. Fazék faltöredéke, fölül háromágú szerszámmal bekarcolt lendületes hullámvonalköteg, alatta négyágú szerszámmal, egymástól egyenetlen távolságra bekarcolt, egyenes vonalkötegek. Ltsz: 2008.1.961.

Oldaltöredék (4. kép 10). M.: 5,5 cm; falvast.: 0,5 cm

Kavicsos homokkal kevert agyag. Kézikorongolt, vegyes égetésú, szürkésbarna, sötétszürke foltos, törésfelülete kívül-belül szürkésbarna, illetve sötétszürke, középen vörösbarna. Oldalán négyágú szerszámmal bekarcolt, vastag hullámvonalkötegek. Ltsz.: 2008.1.965.

Oldaltöredék (4. kép 9). M.: 11,7 cm; falvast.: 0,8 cm

Homokkal kevert agyag. Kézikorongolt, vegyes égetésú, kívül vörösesbarna, belül világosszürke, törésfelülete kívül vörösesbarna, belül szürke. Oldalán több, egymástól egyenetlen távolságra elhelyezkedő fogaskerékdíszsor. Ltsz.: 2008.1.962.

Edény aljának és falának töredéke (4. kép 7). M.: 7,8 cm; falvast.: $0,6-0,8 \mathrm{~cm}$

Apró kavicsos homokkal kevert agyag. Kézikorongolt, vegyes égetésû, szürkésbarna, törésfelülete kívül-belül szürkésbarna, középen vörös. Oldalán a fogaskerékdísz egyes és kettes sorokban váltakozik. Ltsz.: 2008.1.963.
Edény aljának és falának töredéke (4. kép 13). M.: 6,4cm; fátm.: $8 \mathrm{~cm}$; falvast.: $0,7 \mathrm{~cm}$

Homokkal kevert agyag. Kézikorongolt, vegyes égetésû, belül világosbarna, kívül sötétszürke, törésfelülete egyenletes világosbarna. A talpkorongos edényaljra rásimították az enyhe tompaszögben csatlakozó oldalt. A két-, illetve háromfogú szerszámmal bekarcolt egyenes vonalkötegek a talptól 3,5 cm-re érnek véget. Ltsz.: 2008.1.972.

Edény aljának és falának töredéke (5. kép 5). M.: 5,8 cm; fátm.: $10 \mathrm{~cm}$; falvast.: $0,5 \mathrm{~cm}$

Homokkal kevert agyag. Kézikorongolt, vegyes égetésú, szürke, sötétszürke foltos, törésfelülete egyenletes szürke. A talpkorongos edényaljhoz enyhe tompaszögben csatlakozik az oldal, a háromfogú szerszámmal széles sávban bekarcolt egyenes vonalkötegek a talptól 2 cm-re érnek véget, fölöttük hullámvonalköteg töredéke. Ltsz.: 2008.1.980.

Edény aljának és falának töredéke (5. kép 7). M.: $6 \mathrm{~cm}$; fátm.: $10 \mathrm{~cm}$; falvast.: $0,7-1 \mathrm{~cm}$

Apró kavicsos homokkal kevert agyag. Kézikorongolt, barna, sötétszürke foltos, törésfelülete belül barna, kívül sötétszürke. A vékony edényaljhoz enyhe tompaszögben csatlakozik az oldal. A háromfogú szerszámmal igen sekélyen bekarcolt egyenes vonalkötegek a talptól 2,2 cm-re érnek véget. Ltsz.: 2008.1.982.

Edény aljának és falának töredéke (5. kép 4). M.: 4,2cm; fátm.: $11 \mathrm{~cm}$; falvast.:0,7 cm

Homokkal kevert agyag. Kézikorongolt, vegyes égetésú, szürke, belül kormos fekete, törésfelülete egyenletes szürke. A vékony edényaljhoz enyhe tompaszögben csatlakozik az oldal, az ötfogú szerszámmal bekarcolt egyenes vonalköteg a talptól 2,5 cm-re ér véget. Ltsz.: 2008.1.977.

Edény aljának és falának töredéke (5. kép 3). M.: 5,2 cm; fátm.: $12 \mathrm{~cm}$; falvast.: $0,8 \mathrm{~cm}$

Kavicsos homokkal kevert agyag. Kézikorongolt, vegyes égetésú, belül világosbarna, kívül világosszürke, törésfelülete belül világosbarna, kívül világos-, illetve sötétszürke. A vékony edényaljhoz enyhe tompaszögben csatlakozik az oldal. Fenekén a szélétól $1 \mathrm{~cm}$-re domború borda fut körbe. Ltsz.: 2008.1.976.

Edény aljának és falának töredéke (5. kép 6). M: 7,7 cm; fátm.: $12 \mathrm{~cm}$; falvast.: $0,8 \mathrm{~cm}$

Nagyobb kavicsos homokkal kevert, durván eldolgozott agyag. Kézikorongolt, vegyes égetésú, vörös engobos, szürke foltos, törésfelülete kívül-belül vörös, középen szürke. Az edényaljhoz erős tompaszögben csatlakozik az oldal. A kétfogú szerszámmal bekarcolt egyenes vonalköteg a talptól 6 cm-re ér véget. Ltsz.: 2008.1.981. (két darabból ragasztva)

Edény aljának és falának töredéke (5. kép 12). M.: $2 \mathrm{~cm}$; fátm.: $11 \mathrm{~cm}$; falvast.: $0,7 \mathrm{~cm}$

Kavicsos, kevés tört cserepes homokkal kevert agyag. Kézikorongolt, vegyes égetésú, kívül barna, belül sötét- 
szürke, törésfelülete egyenletes barna, illetve sötétszürke. A vastag, egyenetlen felületú edényaljhoz enyhe tompaszögben csatlakozik az oldal. Ltsz.: 2008.1.983. (két darabból ragasztva)

Edény aljának és falának töredéke (5. kép 8). M.: 4 cm; fátm.: 7,5 cm; falvast.: $0,6 \mathrm{~cm}$

Homokkal kevert agyag. Kézikorongolt, vegyes égetésú, barna, szürke foltos, törésfelülete kívül barna, belül sötétszürke. A talpkorongos edényaljhoz enyhe tompaszögben csatlakozik az oldal. A négyfogú szerszámmal bekarcolt egyenes vonalköteg a talptól $3 \mathrm{~cm}$-re ér véget. Talp közepén kisméretú, egyenlő szárú kereszt alakú fenékbélyeg. Ltsz.: 2008.1.984.

Edényalj töredéke (5. kép 13). Maxátm.: $11 \mathrm{~cm}$; falvast.: $0,8-1 \mathrm{~cm}$

Nagyobb kavicsos homokkal kevert agyag. Kézikorongolt, vegyes égetésú, kívül világosszürke, belül sötétszürke, törésfelülete egyenletes szürke. Nagy fazék homorú fenéktöredéke, egyenetlen vastagságú, közepén szabálytalan szárhosszúságú nagyobb kereszt alakú fenékbélyeg, a hosszabb szárak végei elhegyesednek. Ltsz.: 2008.1.979.
Edényalj töredéke (5. kép 11). Maxátm.: 9,8cm; falvast.: $1 \mathrm{~cm}$

Apró kavicsos homokkal kevert agyag. Kézikorongolt, vegyes égetésú, sötétszürke, törésfelülete sötétszürke. Közepén kisméretú, szvasztika alakú fenékbélyeg. Ltsz:: 2008.1.978.

Edényalj töredéke (5. kép 9). Maxátm.: $6 \mathrm{~cm}$; falvast.: $0,5-1 \mathrm{~cm}$

Apró kavicsos homokkal kevert agyag. Kézikorongolt, vegyes égetésú, kívül világosbarna engobos, belül szürkésbarna, törésfelülete kívül világosbarna, belül szürke. Az egyenetlen vastagságú edényalj közepén nagyobb, kereszt alakú fenékbélyeg, a kereszt szárai nem egyenlő szélesek, a hosszú keresztszár elhegyesedik. Ltsz.: 2008.1.985. $0,6 \mathrm{~cm}$

Edényalj töredéke (5. kép 10). Maxátm.: $10 \mathrm{~cm}$; falvast.:

Homokkal kevert agyag. Kézikorongolt, vegyes égetésú, világosbarna, szürke foltos, törésfelülete kívül-belül világosbarna, középen szürke. Közepén nagy, kereszt alakú fenékbélyeg, az egyik szárat harántvonalak metszik, a másik végéhez hegyesszögben vonalak csatlakoznak. Ltsz.: 2008.1.986.

\section{IRODALOM}

LOVAG ZsuZsA

2014 Az Esztergom Prímás-szigeti apácakolostor feltárása (Excavation of the Nunnery on Prímás Island, Esztergom). Opuscula Hungarica 8, Budapest 2014.

\section{MÜNZDATIERTER FRÜHARPADENZEITLICHE FUNDKOMLPEX AUS ESZTERGOM}

\section{ZSUZSA LOVAG}

Die Veröffentlichung des auf der Insel in Esztergom freigelegten, im 11. Jh. gegründeten Nonnenklosters ist 2014 erschienen. (Anm.1.) Das Volumen der Publikation hat nicht ermöglicht von jeden einen Objekte eingehend Mitteilung machen. Es ist aber eine Müllgrube freigelegt, in der auch eine Silbermünze von Andreas I. (1046-1060) gefunden war. Da die Chronologie der Keramik der Arpadenzeit jetzt besonderes Berufsinteresse erregt, es ist nötig die genau datierte Funde der Müllgrube mitteilen.

Die Müllgrube ist unter dem östlichen Gebäudeflügel des Klosters gefunden, der nur am Ende des 13. Jhs., auf eine frühere Kulturschicht mit mehreren Backöfen erbaut war. Unter einem dieser aus Stein gebauten Backöfen war die Müllgrube freigelegt. (Anm.2.)

Die Keramik der Grube ist aussließlich von Fragmenten der kleineren und grösseren Töpfen zusammengestellt, feinere Gefäße oder Bruchstücke der - in anderen Teilen des Klosters sehr häufigen - Tonkessel waren nicht vorhanden.

Der Artikel schildert die typische Bruchstücke der Müllgrube, die im Balassa Museum in Esztergom inventarisiert wurden. 